\title{
Menghadirkan Konsep Hifz Al-Irdi dalam Bermedia Sosial: Upaya Menyikapi Asusila Abu-Abu di Youtube
}

\author{
Saibatul Hamdi ${ }^{1}$ \\ Khabib Musthofa ${ }^{2}$ \\ ${ }^{1}$ Pascasarjana IAIN Palangka Raya \\ ${ }^{2}$ Pascasarjana IAIN Palangka Raya \\ ${ }^{1}$ (email: saibatul98.se@gmail.com) \\ 2(email: khabibmusthofa1996@gmail.com)
}

\begin{abstract}
The phenomenon of gray immorality on YouTube is a problem that has a bad impact, if the content is watched especially for the younger generation. Whereas in fact, in Islam such a phenomenon is considered something that can drop honor. The principle of maqasid sharia has directed the purpose of this life into five basic principles or kulliyat al-khamsah. One of the developments of the five is hifz al-irdi (maintaining honor). So this concept is so important as an effort to address the gray immoral acts on YouTube. The purpose of this paper is to examine: (1) the motive for making gray immoral content; (2) insight into the Koran regarding hifz al-irdi; (3) hifz al-irdi as social media ethics (YouTube). The method used is library research (library research) by exploring and elaborating the verses of the Koran and then connecting them with relevant theories and research. The results of this study indicate that: (1) Gray immoral content has actually become endemic, especially in Indonesian YouTube content. Among the motives for the emergence of the desire to create gray immoral content is due to factors of popularity or fame and because of economic factors or income (financial). (2) There are many verses in the Koran that talk about hifz al-irdi, but one that is relevant is in QS. Al-Baqarah: 273 which talks about the recommendation to maintain honor by not begging. The context of this verse is related to the prohibition of creating bad content for popularity and financial reasons only. (3) Among the Qur'anic guidelines in creating content that upholds hifz al-irdi are content that is not stimulating (approaching adultery), wearing appropriate clothing, and prioritizing the culture of shame.
\end{abstract}

\section{Keywords:}

Hifz al-Irdi, Gray Immorality, YouTube 


\begin{abstract}
Abstrak
Fenomena asusila abu-abu di YouTube menjadi sebuah problem yang berdampak buruk, jika konten-konten tersebut ditonton terutama bagi generasi muda. Padahal sejatinya, dalam Islam fenomena demikian dianggap sesuatu yang dapat menjatuhkan kehormatan. Prinsip maqasid syariah telah mengarahkan tujuan kehidupan ini menjadi lima dasar pokok atau kulliyat al-khamsah. Salah satu pengembangan dari kelimanya adalah hifz al-irdi (menjaga kehormatan). Maka konsep ini begitu penting sebagai upaya menyikapi tindakan asusila abu-abu di YouTube. Tujuan penulisan ini adalah untuk mengkaji tentang: (1) motif pembuatan konten asusila abu-abu; (2) wawasan Alquran mengenai hifz al-irdi; (3) hifz al-irdi sebagai etika bermedia sosial (YouTube). Metode yang digunakan adalah studi kepustakaan (library research) dengan menggali dan mengelaborasi ayat-ayat Alquran kemudian menghubungkannya dengan teori dan penelitian relevan. Hasil kajian ini menunjukkan bahwa: (1) Konten asusila abu-abu sejatinya telah mewabah khususnya pada konten YouTube Indonesia. Di antara motif munculnya keinginan membuat konten asusila abu-abu adalah karena dorongan faktor popularitas atau ketenaran serta karena faktor ekonomi atau pendapatan (finansial). (2) Ada banyak ayat Alquran yang berbicara mengenai hifz al-irdi, namun salah satu yang relevan terdapat dalam QS. Al-Baqarah: 273 yang berbicara tentang anjuran menjaga kehormatan dengan cara tidak meminta-meminta. Konteks ayat ini dihubungkan dengan larangan membuat konten yang buruk hanya untuk popularitas dan finansial belaka. (3) Di antara panduan Alquran dalam membuat konten yang menjunjung tinggi hifz al-irdi adalah konten yang tidak merangsang (mendekati zina), memakai pakaian yang pantas, dan mengutamakan budaya malu.
\end{abstract}

\title{
Kata Kunci:
}

Hifz al-Irdi, Asusila Abu-abu, YouTube

\section{Pendahuluan}

Kimi Hime, seorang YouTuber cantik yang sering menuai kontroversi. Ia kerapkali membuat video yang berisi konten game, namun menggunakan pakaian yang tidak pantas. Akibat ulahnya tersebut pada Agustus 2019 lalu Kominfo memberi teguran atas video yang dinilai sebagai konten asusila abu-abu. ${ }^{1}$ Kasus lain, ada Joe Reny Vlog yang viral dengan judul "Ajak Pacar Cantik Ena-ena, Sempat Ditolak Akhirnya

1 Boyke Ledy Watra, Kominfo Utamakan Pembinaan untuk Konten Asusila "Abu-Abu", https://www.antaranews.com/berita/1006538/kominfo-utamakan-pembinaan-untuk-konten-asusilaabu-abu. 
Menghadirkan Hifz al-Irdi dalam Bermedia Sosial: Upaya Menyikapi Asusila Abu-abu di YouTube Mau", dan sempat trending 3 di YouTube Indonesia. ${ }^{2}$ Potret di atas hanyalah sebagian kecil dari tindak asusila abu-abu yang ada di YouTube. Dikatakan abu-abu dikarenakan menurut Rudiantara konten tersebut masih dipertanyakan pelanggaran asusilanya. $^{3}$

Temuan lain, berdasarkan catatan terbaru dari Kominfo, konten berbau pornografi juga merajai konten negatif Indonesia. Pada Tahun 2018 hingga 2019 lalu, dalam catatan mesin pengais konten negatif (AIS) menemukan sebanyak 898.108 konten yang berbau pornografi. ${ }^{4}$ Meski pada kasus tertentu dinilai abu-abu, namun jika dibiarkan akan terus menggebu-gebu. Sejatinya, Islam telah memperingatkan tentang bahaya konten berbau pornografi yang termasuk ke dalam jalan untuk mendekati zina. Sebuah studi mengejutkan juga datang dari ahli bedah otak University of Texas Donald Hilton Junior menyebut bahwa kerusakan otak akibat pornografi sama dengan kerusakan akibat kecelakaan yang parah. Mari kita bayangkan, jika virus berbahaya ini menggerogoti generasi muda akan ada banyak kebobrokan yang mencuat. ${ }^{5}$

Kondisi diperparah ketika pornografi menjadi tontotan sedap di media sosial seperti YouTube. Menurut Pew Research, YouTube adalah jejaring sosial terbesar kedua setelah Facebook. Pengguna YouTube berada pada usia antara 18 hingga 29 tahun dengan persentase $82 \% .^{6}$ Sementara We are Social menyebut YouTube menjadi

2 Sally Siahan, YouTuber Ajak Pacar Cantik 'Enak-enak' jadi Trending Youtube, Sempat Ditolak, Akhirnya Mau?, https://medan.tribunnews.com/2019/10/10/youtuber-ajak-pacar-cantik-enakenak-jadi-trending-youtube-sempat-ditolak-akhirnya-mau?page $=3$.

${ }^{3}$ Kominfo, https://kominfo.go.id/content/detail/20636/kominfo-utamakan-pembinaan-untukkonten-asusila-abu-abu/0/sorotan_media

4 Kominfo, Pornografi Masih Merajai Konten Negatif Indonesia, https://kominfo.go.id/content/detail/19631/pornografi-masih-merajai-konten-negatif-internetindonesia/0/sorotan_media

${ }^{5}$ Kementerian Pemberdayaan Perempuan dan Perlindungan Anak Republik Indonesia, Modul Creative Digital Education, 2017, https://www.kemenpppa.go.id/lib/uploads/list/990b7-creative-digitaleducation.pdf.

6 CNN Indonesia, https://www.cnnindonesia.com/teknologi/20150214143544-18532127/youtube-dalam-angka-angka. 
platform media sosial yang paling banyak digandrungi di Indonesia dengan persentase $43 \%$ dari 130 juta orang. ${ }^{7}$

Di tengah ramainya penggunaan Youtube, sebenarnya Alquran menyimpan pesan tersirat tentang etika dalam bermedia sosial. Seperti yang diceritakan dalam QS. Al-Maidah ayat 35 yang mengisyaratkan untuk mencari وصيلة atau media guna mendekatkan diri kepada Allah Swt. ${ }^{8}$ Begitupun sebenarnya dalam bermedia sosial, sudah semestinya digunakan untuk mendekatkan diri kepada Allah Swt, bukan malah sebaliknya. Namun fakta mencengangkan akhir-akhir ini telah cukup jelas untuk menjawabnya.

Pesan penting di atas sudah sepatutnya menjadi pengingat untuk bijak dalam bertindak. Di tengah maraknya konten asusila abu-abu menandakan bahwa ada sesuatu yang hilang, yaitu nilai-nilai muruah (kehormatan). Tentang upaya menjaga kehormatan merupakan manifestasi dari konsep hifz al-irdi. Konsep ini penting, bukan hanya berbicara pada ranah melindungi diri dari hinaan dan sebagainya, namun sebagai suatu pedoman yang menjamin harkat dan martabat manusia. Maka hifz alirdi ini berusaha untuk memelihara diri agar tidak terjerumus ke dalam perbuatan yang terlarang. ${ }^{9}$

Nilai-nilai hifz ai-Irdi tersebut yang perlu dihadirkan dan harus dimiliki setiap individu pengguna media sosial. Karena orang-orang yang paham akan pentingnya kehormatan dirinya akan berhati-hati dan memilah konten yang pantas untuk dibuat atau dibagikan. Sehingga secara tidak langsung akan menjadi peredam maraknya konten asusila abu abu. Selain itu, konsep hifz al-irdi sejatinya dapat diwujudkan melalui dukungan langkah konkret yang konsisten dan terarah.

7 Agus Tri Haryanto, https://inet.detik.com/cyberlife/d-3912429/130-juta-orang-indonesiatercatat-aktif-di-medsos.

${ }^{8}$ Quraish Shihab, Tafsir Al-Misbah: Pesan, Kesan, dan Keserasian al-Qur'an, (Jakarta: Lentera Hati, 2009), hlm. 107.

9 Syahrul Sidiq, "Maqasid Syari' ah dan Tantangan Modernitas: Sebuah Telaah Pemikiran Jasser Auda", Jurnal Agama dan Hak Azazi Manusia, Vol 07, No. 01, 2017, hlm. 155.

144 | El Madani: Jurnal Dakwah dan Komunikasi Islam, Volume 1 No. 02 (2020) 
Menghadirkan Hifz al-Irdi dalam Bermedia Sosial: Upaya Menyikapi Asusila Abu-abu di YouTube

Artikel ini bertujuan untuk mengkaji tentang (1) melacak motif munculnya konten asusila abu-abu di YouTube. (2) Wawasan Alquran tentang hifz al-irdi. (3) hifz al-irdi sebagai etika bermedia sosial khususnya di YouTube.

\section{Metode Penelitian}

Metode yang digunakan dalam penulisan artikel ini adalah kajian pustaka (library reserach). Kajian ini menekankan kepada studi terhadap literatur-literatur yang sesuai dengan objek kajian penelitian. ${ }^{10}$ Kajian ini berusaha untuk menganalisis konsep hifz al-irdi sebagai bagian dari maqasid syari'ah dan elaborasi ayat Alquran yang terkait hal tersebut. Kemudian merumuskan solusi berdasarkan prinsip hifz al-irdi dalam kontekstualisasi Alquran guna menyikapi asusila abu-abu sebagai masalah yang dibahas dalam artikel ini.

\section{Melacak Motif Konten Asusila Abu-abu, Sensasi atau Ekonomi?}

Bicara tentang asusila, Kamus Besar Bahasa Indonesia (KBBI) memaknainya dengan tidak susila atau tidak baik tingkah lakunya. ${ }^{11}$ Secara khusus, asusila adalah perbuatan atau tingkah laku yang menyimpang dari norma-norma atau kaidah kesopanan yang banyak terjadi di masyarakat. ${ }^{12}$ Teranyar, Kominfo pada 2019 lalu membuat satu istilah baru yaitu asusila abu-abu. Menteri Komunikasi dan Informatika, Rudiantara menyebut bahwa asusila abu-abu merupakan tindakan yang masih dipertanyakan pelanggaran asusilanya, namun jika dibiarkan akan membahayakan dan menggerus budaya ketimuran. ${ }^{13}$

${ }_{10}$ Mestika Zed, Metode Penelitian Kepustakaa, (Jakarta: Yayasan Pustaka Obor Indonesia, 2014), hlm. 81 .

11 Tim Redaksi KBBI, Kamus Besar Bahasa Indonesia, (Jakarta: Badan Pengembangan dan Pembinaan Bahasa Kementerian Pendidikan dan Kebudayaan, 2017), hlm. 125.

12 Harinal Setiawan, "Peranan Kepolisian dalam Menanggulangi Tindak Pidana Kejahatan Asusila yang Dilakukan Orang Dewasa terhadap Anak di Kota Pekanbaru", Jurnal Fakultas Hukum, Vol. 01, No. 02, 2014, hlm. 1.

13 Kominfo,.... 
Asusila abu-abu yang dimaksud dapat berupa tontonan dengan pakaian terbuka atau tindakan yang mendekati porno seperti fenomena mengajak berhubungan badan namun tidak dilaksanakan. Biasanya video-video YouTube semacam ini dibuat hanya untuk menarik pengguna untuk menontonnya. Para YouTuber mengemasnya dengan judul atau foto depan yang bernuansa pornografi sehingga mengundang mata dan jari yang tidak bertanggung jawab untuk mengaksesnya.

Dalam sebuah studi dijelaskan bahwa ada beberapa faktor yang mempengaruhi seorang YouTuber untuk membuat konten yang menarik viewer. Di antara faktor yang paling dominan adalah sebagai berikut. ${ }^{14}$

\section{Popularitas}

Tidak sedikit orang di dunia ini yang menganggap bahwa popularitas merupakan sumber kebahagiaan. Alhasil, berbagai cara dilakukan hanya untuk meraih popularitas semata. Padahal sejatinya, anggapan tersebut tidaklah selamanya benar. Tak sedikit pula orang yang tersiksa dengan popularitas yang dimilikinya. Anggapan ini sering terlontar dari mereka yang memiliki beban psikologis. ${ }^{15}$

Bagi YouTuber, popularitas menjadi hal penting sebagai motivasi dalam membuat konten yang menarik. Terlihat dari setiap opening video yang ditampilkan, selalu ada himbauan subscribe, like, dan comment untuk video tersebut. ${ }^{16}$ Selain itu mereka juga memancing viewersnya dengan judul yang menarik perhatian. Setelah mereka mendapatkan subscriber yang banyak, maka channel YouTube tersebut akan terkenal dan semakin sering untuk dikunjungi.

${ }^{14}$ Ulfa Dewi Solikhah, Analisis Faktor yang Mempengaruhi Minat Pengguna Menjadikan YouTube Sebagai Sumber Penghasilan (Persepsi pada Mahasiswa Akuntansi Universitas Islam Indonesia). Skripsi, Universitas Islam Indonesia, 2018, hlm. 70

${ }^{15}$ Surbakti, E.b, Gangguan Kebahagiaan Anda dan Solusinya (Jakarta: Alex Media Komputindo, 2010), hlm. 390.

${ }_{16}$ Ulfah Dewi Solikhah, Analisis Faktor yang Mempengaruhi Minat Pengguna Menjadikan YouTube Sebagai Sumber Penghasilan....

146 | El Madani: Jurnal Dakwah dan Komunikasi Islam, Volume 1 No. 02 (2020) 
Menghadirkan Hifz al-Irdi dalam Bermedia Sosial: Upaya Menyikapi Asusila Abu-abu di YouTube Penghargaan Finansial

Penghargaan finansial merupakan penghargaan yang diberikan seseorang berupa imbalan sebagai konsekuensi dari pekerjaan yang telah dilaksanakan dengan jangka waktu atau jumlah tertentu. ${ }^{17}$ Para YouTuber akan memperoleh penghargaan finansial berupa uang yang diberikan oleh YouTube sebagai imbalan atas kontenkonten yang telah mereka buat. ${ }^{18}$ Subscriber dan viewers yang banyak mengantar channelnya trending, maka penghasilan pun akan semakin bertambah.

Dua faktor di atas menjadi alasan mengapa para YouTuber memiliki cara masing-masing agar channel YouTubenya diminati. Ironisnya, tujuan ini terkadang disalahgunakan oleh pihak yang haus akan duniawi. Mereka rela menghalalkan segala cara termasuk mengumbar sesuatu yang tak pantas di YouTube. Hal ini membuktikan bahwa fenomena asusila abu-abu yang marak terjadi didasari karena menambah popularitas (sensasi) yang diikuti oleh pendapatan penghasilan dari pihak YouTube (ekonomi).

\section{Wawasan Alquran tentang Hifz al-Irdi}

Bertolak dari permasalahan asusila abu-abu di YouTube ini, penulis berusaha untuk menggagas sebuah konsep maqasid syariah untuk ditawarkan sebagai solusi. Konsep yang diutarakan beberapa ahli seperti 'Abd. Al-Wahhab ibn Ali al-Subki dan Muhammad ibn Abdullah al-Zarkasy adalah hifz al-'irdi. ${ }^{19}$ Secara bahasa, hifz

${ }_{17}$ Abdullah dan Irra Hegwisi, KPI A to Z: Panduan Implementasi KPI yang Workable, (Jakarta: Grasindo, 2017), hlm. 90.

${ }_{18}$ Ulfah Dewi Solikhah, Analisis Faktor yang Mempengaruhi Minat Pengguna Menjadikan YouTube Sebagai Sumber Penghasilan....

${ }^{19}$ Busyro, Maqasid al-Syariah: Pengetahuan Mendasar Memahami Masalah, (Jakarta: Prenadamedia Group, 2019), hlm, 210. 
dimaknai dengan "menjaga atau memelihara" ${ }^{20}$ sedangkan al-irdi adalah "kehormatan". ${ }^{21}$

Jasser Auda dalam bukunya menjelaskan tentang tujuan maqasid syariah adalah sebagai berikut.

"Traditional classifications of maqasid divide the into there 'levels of necessity,' which are necessities (darurat), needs (hajiyat), and luxuries (tahsiniyat). Necessities are futher classified into what 'preserves one's faith, soul, wealth, mind, and offspring. Some usulis added 'the preservation of 'honor' to the above five widely popular necessities." 22

Artinya: "Klasifikasi tradisional membagi maqasid syariah hanya pada tingkatan keniscayaan, yaitu keniscayaan atau daruriat, kebutuhan atau hajiat, dan kelengkapan atau tahsiniat. Daruriat sendiri dibagi kembali menjadi lima yaitu, hifz ad-din (perlindungan agama), hifz an-nafs (perlindungan jiwa raga), hifz al-mal (perlindungan harta), hifz al-'aql (perlindungan akal), dan hifz an-nasl (perlindungan keturunan). Kemudian beberapa ahli figh menambahkan hifz alirdi (perlindungan kehormatan) selain lima dasar di atas."

Terkait dengan hifz al-irdi, al-Juwaini menyebut istilah ini dengan 'penjagaan kehormatan'. Konsep ini menjadi konsep sentral kebudayaan Arab yang telah ada pada zaman dahulu, tepatnya sebelum Islam datang. Ketika itu, seorang penyair bernama Antarah yang bertengkar dengan kabilah damdam terkait dengan 'pencemaran kehormatannya'. Rasulullah pun menjelaskan bahwa darah, harta, dan kehormatan setiap muslim adalah 'haram', yang tidak boleh dilanggar. Namun, dewasa ini istilah 'perlindungan kehormatan' menjadi lebih luas yaitu perlindungan harkat martabat dan hak asasi. ${ }^{23}$

Perluasan makna hifz al-irdi menunjukkan bahwa tujuan syariah sangat memperhatikan nilai-nilai utama yang harus dipertahankan. Sebab kenyataan yang

${ }_{20}$ Mahmud Yunus, Kamus Arab-Indonesia, (Jakarta: Mahmud Yunus Wadzuryah, 1990), hlm. 105.

21 Syahrul Sidiq, "Maqasid Syari'ah dan Tantangan Modernitas: Sebuah Telaah Pemikiran Jasser Auda", ...hlm. 155.

22 Jasser Auda, Maqasid al-Shariah as Philosophy of Islamic Law: a Sistem Approach, (Malaysia: Vinlin Press, 2010), hlm. 3.

${ }^{23}$ Jasser Auda, Membumikan Hukum Islam Melalui Maqasid Syariah, terj. Rosidin dan Ali Abd elMun'im, (Bandung: Mizan Media Utama, 2015), hlm. 57. 
Menghadirkan Hifz al-Irdi dalam Bermedia Sosial: Upaya Menyikapi Asusila Abu-abu di YouTube dihadapi tentu akan berbeda pada setiap zaman yang berkembang. Bukan hanya itu, tingkat kerumitan permasalahan menjadi sesuatu yang amat penting untuk diulas kembali dan disesuaikan. Misalnya saja tentang persoalan asusila abu-abu di media sosial ini dapat menjadi serasi dengan konsep hifz al-irdi karena penjagaan kehormatan yang sesungguhnya terjadi pada berbagai hal keadaan.

Hifz al-irdi bukan hanya berbicara pada ranah melindungi diri dari hinaan dan sebagainya, namun sebagai suatu pedoman yang menjamin harkat dan martabat manusia. Maka hifz al-irdi ini berusaha untuk memelihara diri agar tidak terjerumus ke dalam perbuatan yang terlarang. Selain itu, hifz al-irdi sebagai salah satu upaya untuk menghindari fitnah terutama terhadap kasus pornografi yang marak terjadi. ${ }^{24}$

Berkenaan dengan konsep hifz al-irdi, secara normatif memiliki dasar yang kuat dalam Alquran. Hal ini karena ada banyak ayat yang mengisyaratkan pentingnya untuk menjaga kehormatan. Islam hanya menginginkan pemeluknya menjadi umat yang terhormat serta mendapatkan kemuliaan agar terbebas dari hinaan dan permasalahan. ${ }^{25}$ Salah satu bentuk dalam menjaga kehormatan adalah dengan tidak mengumbar rahasia pribadi. Hal ini sangat terkait dengan fenomena asusila abu-abu yang memamerkan sesuatu yang tidak pantas ke depan umum. Sebab perbuatan tersebut akan mencederai kehormatan diri. ${ }^{26}$

Konsep Hifz al-Irdi sejatinya telah disinggung dalam Alquran, sebagaimana terdapat pada firman Allah berikut.

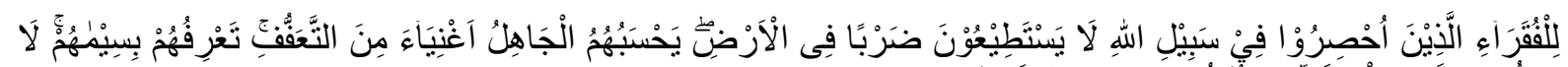

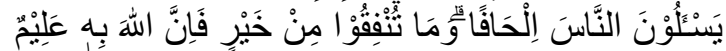
Artinya: “273. (Apa yang kamu infakkan) adalah untuk orang-orang fakir yang terhalang (usahanya karena jihad) di jalan Allah, sehingga dia yang tidak dapat berusaha di bumi; (orang lain) yang tidak tahu, menyangka bahwa mereka adalah orang-orang kaya karena mereka menjaga diri (dari meminta-minta). Engkau (Muhammad) mengenal mereka dari ciri-cirinya,

${ }^{24}$ Syahrul Sidiq, "Maqasid Syari'ah dan Tantangan Modernitas: Sebuah Telaah Pemikiran Jasser Auda", ...hlm. 155.

${ }^{25}$ Wajih Mahmud, Siapa Bilang Bersedekah Harus Tunggu Kaya?, (Jakarta: Mizan, 2012), hlm. 195.

${ }^{26}$ Nasrullah, Resep Hidup Bahagia Menurut al-Qur'an, (Jakarta: Pustaka Alvabet, 2019), hlm. 136. 
mereka tidak meminta secara paksa kepada orang lain. Apa pun harta yang baik yang kamu infakkan, sungguh, Allah Maha Mengetahui."27

Ibnu Katsir dalam tafsirnya menjelaskan bahwa ${ }^{28}$ :

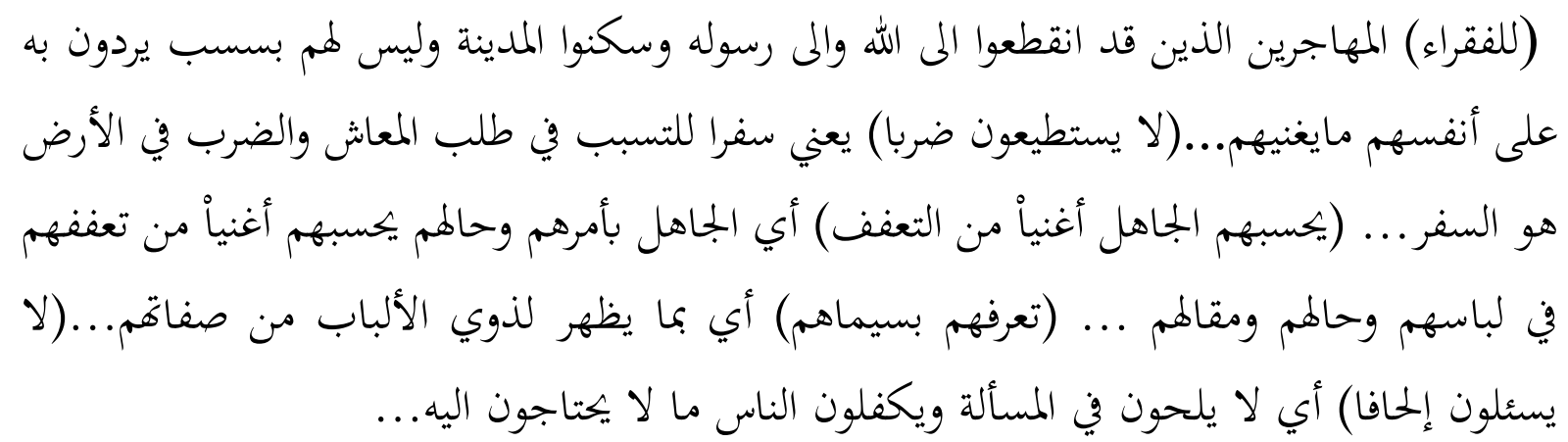

Dalam penjelasannya tersebut, Ibnu Katsir menyebut orang-orang Faqir yang dimaksud dalam ayat tersebut yakni orang-orang muhajirin yang telah meninggalkan segala kekayaan di Mekkah kemudian tinggal di Madinah belum mendapatkan usaha untuk mencukupi kebutuhan hidupnya. Kemudian mereka tidak dapat melakukan aktivitas di bumi karena terikat dengan Jihadnya. Namun orang-orang mengira bahwa mereka adalah orang kaya karena perilakunya yang tidak meminta-meminta. Hal tersebut terlihat dari tanda-tanda yang tampak dari diri mereka. Selain itu mereka juga tidak suka meminta-minta kepada orang lain dengan cara memaksa.

Shihab juga menjelaskan bahwa ayat di atas menjelaskan tentang orang-orang fakir yang disebabkan sibuk jihad di jalan Allah sehingga tidak dapat memperoleh peluang bekerja untuk memenuhi kebutuhan. Mereka adalah orang-orang terhormat, bersih walau miskin, rapi walau sederhana, taat beragama, dan menghargai diri mereka. Sampai ketika orang lain melihat tidak akan menyangka mereka adalah orang fakir karena enggan meminta-minta. ${ }^{29}$

Sayyid Quthb menambahkan penjelasan ayat tersebut dengan mengibaratkan orang-orang fakir mulia yang menyembunyikan kebutuhannya itu seakan-akan seperti menutup aurat mereka. Sehingga mereka tidak menodai dan melukai

${ }^{27}$ QS. Al-Baqarah [2]: 273.

${ }^{28}$ Al-Imam Abul Fida Ismail Ibnu Katsir ad-Dimasyqi, Tafsor al-Qur'anul 'Azhim, (Beirut: Darul Fikr, 1983), hlm. 575-576.

${ }^{29}$ Quraish Shihab, Tafsir Al-Misbah: Pesan, Kesan, dan Keserasian al-Qur'an Vol 1, ...hlm. 710. 
Menghadirkan Hifz al-Irdi dalam Bermedia Sosial: Upaya Menyikapi Asusila Abu-abu di YouTube kehormatannya sedikit pun. Sejatinya ayat ini juga berpesan kepada orang yang berinfaq untuk memberikannya secara rahasia agar hanya ia sendiri yang tahu dan kebaikan di sisi-Nya tidak akan sia-sia. ${ }^{30}$

Pesan tersirat ayat di atas adalah 'larangan untuk meminta-minta' meski dalam kondisi yang sulit. Manusia sejatinya diberikan kekuatan untuk bisa bangkit dari permasalahan yang dihadapinya dengan jalan berikhtiar. Hal serupa telah dicontohkan pada orang-orang Muhajirin yang mampu terlihat berwibawa, kuat, bahkan terlihat seperti orang kaya padahal mereka sedang dilanda kesusahan. Sikap bijak yang tidak meminta-minta menjadikan pribadi mereka sangat terhormat.

Wacana inilah kiranya menjadi pelajaran di era sekarang untuk bijak dalam bertindak, bukan mengerjakan berbagai cara hanya untuk pelampiasan kehendak. Bukan tentang uang atau kufur nikmat, tetapi tentang penjagaan muru'ah atau martabat. Maka sepantasnya untuk memelihara tindakan guna menjaga kehormatan sebagaimana tersirat dalam pesan Alquran.

Jika dihubungkan dengan fenomena asusila abu-abu, seorang YouTuber hendaknya tidak menodai kehormatannya dengan melakukan hal yang tidak pantas hanya untuk mendapatkan royalti ataupun ketenaran. Meskipun perbuatan tersebut tidaklah melakukan hal yang sebenarnya seperti zina, namun akan membawa kepada sesuatu yang tidak pantas ditampilkan. Senada dengan hal ini, kaidah Fiqih mengatakan bahwa:

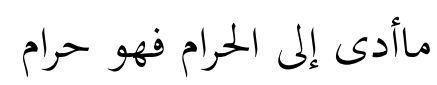

Artinya: “Apa yang membawa kepada haram maka hal tersebut juga haram hukumnya".

Maka jelaslah bahwa asusila abu-abu dapat membangkitkan nafsu dengan adegan panas meski pura-pura ataupun terbukanya pakaian meski tidak bertujuan hlm. 371.

${ }^{30}$ Sayyid Quthb, Tafsir Fi Zhilalil Qur'an. Terj. As'ad Yasin dkk, (Jakarta: Gema Insani, 2013), 
pornografi. Berdasarkan kaidah Fiqih tersebut, hukumnya tetaplah haram untuk dilakukan. ${ }^{31}$

Sejatinya panduan Alquran ini mengisyaratkan tentang larangan mendekati dan melakukan sesuatu yang menodai kehormatan. Namun faktanya, fenomena menyedihkan semakin marak terjadi, para YouTuber yang haus akan viewer selalu menuai sensasi tanpa mengindahkan kehormatan dirinya. Maka sepatutnya ramburambu Alquran perlu semakin ditegaskan dan digaungkan agar pesan penting ini dapat terlaksana. Sebab penjagaan murur'ah atau kehormatan ini menjadi salah satu tujuan syariah yang juga merupakan bagian dari menjaga agama.

\section{Hifz al-Irdi Sebagai Etika Bermedia Sosial (YouTube)}

Menindaklanjuti QS. Al-Baqarah: 273 di atas, terdapat panduan penting dalam memelihara kehormatan diri dalam bermedia sosial khususnya yang terkait dengan fenomena asusila abu-abu di YouTube, dengan beberapa petunjuk yaitu sebagai berikut.

\section{Jangan Mendekati Zina!}

Fenomena asusila abu-abu memang bukan termasuk ke dalam perbuatan zina, namun perbuatan tersebut berpotensi untuk merangsang dan menimbulkan nafsu seksual. Berkenaan dengan hal ini, Alquran telah menegaskan dalam QS. Al-Isra sebagai berikut.

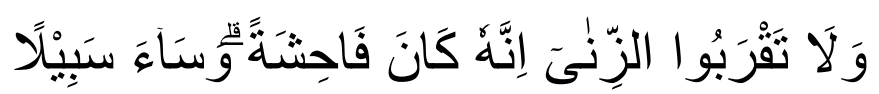

Artinya: “32. Dan janganlah kamu mendekati zina; Sesungguhnya zina itu adalah suatu perbuatan yang keji. dan suatu jalan yang buruk". (QS. Al-Isra: 32)

Imam Al-Qurthubi menjelaskan bahwa kata la taqrabuz zina (janganlah kalian mendekati zina) lebih mendalam dibandingkan dengan la taznu (janganlah kalian semua berzina). Hal ini karena kata la taqrabu lebih bersifat pencegahan dan upaya

${ }^{31}$ Dzajuli, Kaidah-Kaidah Fikih: Kaidah-kaidah Hukum Islam dalam Menyelesaikan Masalah-Masalah yang Praktis, (Jakarta: Kencana, 2007), hlm. 32.

152 | El Madani: Jurnal Dakwah dan Komunikasi Islam, Volume 1 No. 02 (2020) 
Menghadirkan Hifz al-Irdi dalam Bermedia Sosial: Upaya Menyikapi Asusila Abu-abu di YouTube yang lebih awal dilakukan. Demikian juga kata sabilan yaitu jalan yang seburukburuknya. Hal ini karena zina termasuk ke dalam perbuatan dosa besar dan menimbulkan keburukan.32 Demikian Shihab juga menjelaskan korelasi antara la taqrabu dan sa'a sabilan adalah larangan untuk mendekati sesuatu yang dapat membawa kepada jalan neraka yaitu perzinahan. ${ }^{33}$

Dapat dipahami bahwa ayat ini sebagai upaya pencegahan agar terhindar dari perbuatan zina. Sehingga segala tindakan yang mendekatinya harus dihindari, misalnya berpelukan, berciuman, ataupun berkata-kata yang merangsang. Terlebih lagi hal itu dilakukan dengan direkam, justru akan semakin besar dampak yang ditimbulkan. Selain mendekatkan diri sendiri, juga dapat mempengaruhi orang lain untuk berbuat demikian.

Selain itu, kaidah Fiqih juga menyebutkan bahwa:

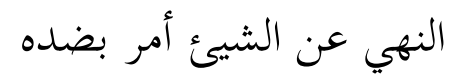

"Larangan terhadap sesuatu, berarti perintah terhadap Dhid-dhid-nya (lawanlawannya)".

Hal ini berarti ketika Allah memberikan larangan untuk tidak mendekati zina dalam ayat di atas, maka sesungguhnya perintah yang tersirat adalah menjauhi perbuatan tersebut. Dengan demikian bahwa kata la taqrabu dalam ayat tersebut berfungsi sebagai ancaman (للتهديد) bagi manusia. ${ }^{34}$

Ibn Qayyim al-Jauziyah menjelaskan bahwa menjaga kehormatan merupakan suatu kewajiban yang akan terus ada pada diri setiap individu. Ketika ia berbuat sesuatu yang dianggap tidak baik, maka cacatlah kehormatannya. Sebaliknya, jika ia

${ }^{32}$ Syaikh Imam Al-Qurthubi, Tafsir Al-Qurthubi Jilid 10. Terj. Asmuni, (Jakarta: Pustaka Azzam, 2008), hlm. 627. ....hlm. 80 .

${ }^{33}$ Quraish Shihab, Quraish Shihab, Tafsir Al-Misbah: Pesan, Kesan, dan Keserasian al-Qur'an,

${ }^{34}$ A. Basiq Djalil, Ilmu Ushul Figh, (Jakarta: Kencana Prenada Media Group, 2010), hlm. 64. 
memeliharanya, maka akan semakin dipandang baik harkat dan martabatnya. Dengan demikian, kehormatan seseorang dipegang oleh dirinya sendiri. ${ }^{35}$

Peran agamawan sangat diperlukan untuk terus mensosialisasikan pesanpesan penting terkait menjaga kehormatan melalui mimbar-mimbar khutbahnya. Tidak berhenti pada ranah mimbar dakwah, pesan penting ini hendaknya juga disampaikan melalui literasi dan media sosial. Terkait hal ini, YouTube sebenarnya dapat dijadikan media dakwah yang efektif. Sebab melalui YouTube, penyebaran pesan penting ini akan semakin mudah tersampaikan.

Upaya lain adalah adanya penegasan dari pihak YouTube dan Kominfo terkhusus untuk YouTube Indonesia. Pertama, mempertegas peraturan mengenai konten yang berbau pornografi ataupun yang mendekatinya seperti asusila abu-abu. Kedua, menyeleksi judul dan isi dari setiap konten menggunakan mesin pendeteksi, misalnya dengan kata kunci 'prank wik-wik' dan sebagainya. Ketiga, konten yang mengarah kepada perbuatan tidak senonoh meskipun hanya hiburan dibuat menjadi copyrighted (pelanggaran hak cipta) sehingga video yang diupload tidak akan menghasilkan apapun.

\section{Memakai Pakaian yang Pantas}

Kriteria pakaian yang pantas terkhusus bagi muslim dan muslimah sejatinya telah tergambar dalam Alquran sebagaimana dalam Qs. An-Nur ayat 31 sebagai berikut.

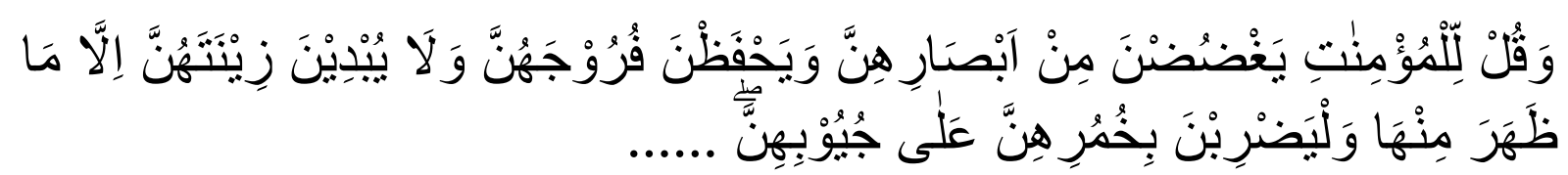

Artinya: “31. Katakanlah kepada wanita yang beriman: "Hendaklah mereka menahan pandangannya, dan kemaluannya, dan janganlah mereka Menampakkan perhiasannya, kecuali yang (biasa) nampak dari padanya. dan hendaklah mereka menutupkan kain kudung kedadanya, ...". ${ }^{36}$

${ }^{35}$ Ibn Qayyim al-Jauziyah, Kiat Membersihkan Hati dari Kotoran Maksiat. Terj. Fauzi Bahreisy, (Jakarta: Serambi Ilmu Semesta, 2008), hlm. 58.

${ }^{36}$ QS. An-Nur [24]: 31. 
Menghadirkan Hifz al-Irdi dalam Bermedia Sosial: Upaya Menyikapi Asusila Abu-abu di YouTube

Diriwayatkan dari Ibnu Abi Hatim dari Jabir bin Abdillah, ayat ini turun berkenaan dengan Asma' binti Murtsid pemilik kebun kurma, sering dikunjungi oleh wanita. Mereka bermain di kebunnya tanpa berkain panjang, sehingga kelihatan gelang kakinya. Demikian juga dada dan sanggul mereka. Maka Asma' pun berkata: "Alangkah buruknya pemandangan ini". Sehubungan dengan hal tersebut, maka ayat ini turun sebagai larangan bagi orang beriman untuk membiarkan mata berkeliaran. ${ }^{37}$

Ibnu Katsir dalam tafsirnya menjelaskan bahwa ayat di atas merupakan perintah Allah Swt kepada mukminat agar menahan pandangannya dari yang diharamkan, memelihara kemaluan, dan tidak menampakkan perhiasan (bagian tubuh) kecuali apa yang biasa tampak. Perhiasan yang biasa tampak adalah wajah dan kedua telapak tangan. Selain itu, ayat ini juga memerintahkan kepada perempuan untuk mengulurkan kerudungnya sampai ke dada. ${ }^{38}$ Shihab menyebut dada dada sebagai hiasan pokok yang ada pada seorang wanita. Sehingga terdapat larangan untuk mengumbarnya. ${ }^{39}$

Ringkas kata, pakaian yang pantas bagi seorang wanita adalah pakaian yang wajar untuk digunakan dengan tidak menampakkan perhiasan yang ada pada dirinya. Bukan hanya berfungsi menutup aurat, tetapi juga senantiasa menjaga kesopanan dan menunjukkan keanggunan dari pribadi seorang wanita. ${ }^{40}$ Salah satunya Shihab menyebut jilbab menjadi pakaian pembeda antara hamba sahaya dan wanita-wanita yang terhormat. ${ }^{41}$

Ayat di atas lebih menitikberatkan kepada wanita, karena realita yang kini terjadi pun lebih banyak berkaitan dengan wanita. Misalnya fenomena YouTuber seksi yang memperlihatkan lekuk tubuhnya. Maka upaya pendekatan harus dilakukan

37 A. Mujab Mahali, Asbabun Nuzul: Studi Pendalaman Al-Qur'an, (Jakarta: PT Raja Grafindo Persada, 2002), hlm. 619-620.

38 Ibnu Katsir, Terjemah Singkat Tafsir Ibnu Katsir, terj. Salim Bahresy dan Said Bahresy, (Surabaya: PT Bina Ilmu, 2002), hlm. 467.

${ }^{39}$ Quraish Shihab, Tafsir Al-Misbah: Pesan, Kesan, dan Keserasian al-Qur'an, ....hlm. 526.

${ }^{40}$ Muhammad Baghir, Panduan Lengkap Ibadah Menurut Al-Qur'an, Al-Sunnah, dan Pendapat Para Ulama, (Jakarta: Naura Books, 2015), hlm. 96.

${ }^{41}$ Quraish Shihab, Jilbab, Pakaian Wanita Muslimah, (Jakarta: Lentera Hati, 2012), hlm. 216. 
salah satunya melalui dakwah muslimah milenial tentang fashion Islami zaman now. Misi ini dapat dilakukan melalui Instagram, YouTube, Facebook, dan lain-lain atau melalui komunitas khusus yang dibentuk untuk memberi edukasi mengenai fashion kekinian namun tetap mempertahankan nilai-nilai Islam maupun kesusilaan. Bentuk kegiatan yang dilakukan dapat melalui event 'Muslimah Fashion and Style Festival' yang mengedukasi tentang cara berpakaian serta mengapresiasi karya mereka.

Upaya ini harus sejalan dengan gerakan pemerintah bersama Kominfo untuk meningkatkan pengawasan dan pengendalian terhadap Channel YouTube yang menampilkan pemandangan tidak pantas. Sebagaimana yang telah dilakukan oleh Kominfo kepada Kimi Hime dalam upaya pembinaan agar lebih bijak dalam membuat konten YouTube. Aksi ini juga akan berhasil jika edukasi kepada viewer juga dilakukan agar tidak sembarang dalam menonton atau mengakses video yang mengandung unsur tidak senonoh.

\section{Membudayakan Rasa Malu}

Rasa malu menjadi amat penting untuk dimiliki oleh setiap orang. Malu yang dimaksud adalah ketika mengerjakan suatu keburukan. Hal ini juga menjadi bagian dari menjaga kehormatan. Rasulullah Saw bersabda:

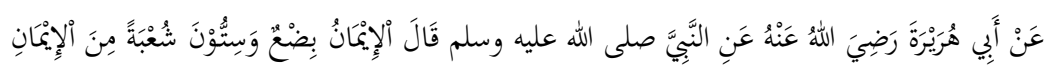

Artinya: "Dari Abi Hurairah RA, Nabi Saw bersabda, "Iman mempunyai lebih dari enam puluh cabang. Adapun malu adalah salah satu cabang dari iman." 42

Hadis di atas berbicara tentang iman dan salah satu bagian dari iman adalah malu. Ibnu Hajar al-Asqalani dalam kitabnya menjelaskan bahwa al-haya' atau malu berarti perubahan yang ada pada diri seseorang karena takut melakukan perbuatan yang menimbulkan aib. Malu dikatakan menjadi cabang daripada iman karena dapat menjadi faktor stimulus yang melahirkan perbuatan taat dan dapat membentengi diri

${ }^{42}$ HR. Bukhari dan Muslim. 
Menghadirkan Hifz al-Irdi dalam Bermedia Sosial: Upaya Menyikapi Asusila Abu-abu di YouTube dari perbuatan maksiat. Oleh karenanya malu dapat menjadi motivator untuk memunculkan cabang iman yang lain. ${ }^{43}$

Demikianlah rasa malu untuk berbuat maksiat harus ditanamkan pada diri setiap manusia yang beriman. Hal ini karena Allah mengetahui segala perbuatan manusia, sehingga Allah mengutus para malaikat untuk mencatat setiap amal perbuatan manusia. Sebagaimana dalam firman-Nya sebagai berikut.

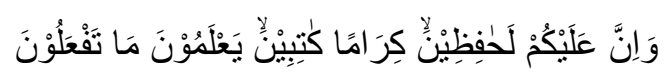

Artinya: “10. Padahal Sesungguhnya bagi kamu ada (malaikat-malaikat) yang mengawasi (pekerjaanmu), 11. Yang mulia (di sisi Allah) dan mencatat (pekerjaanpekerjaanmu itu), 12. Mereka mengetahui apa yang kamu kerjakan". ${ }^{44}$

و إن عليكم Imam Al-Qurthubi dalam tafsirnya menjelaskan maksud dari kalimat " لحفظين padahal sesungguhnya bagi kamu ada yang mengawasi," yaitu pengawas yang berasal dari golongan malaikat. ${ }^{45}$ Shihab juga menambahkan bahwa kalimat tersebut ditujukan kepada semua manusia yang mukallaf (dewasa dan berakal) tanpa terkecuali. Demikian pula kata على yang terdapat dalam firman-Nya على mengisyaratkan betapa besar kuasa malaikat untuk mengawasi dan memperhatikan perbuatan manusia. Apalagi Allah yang berada pada kedudukan lebih tinggi dari malaikat. ${ }^{46}$

Ayat di atas mengisyaratkan bahwa gerak-gerik manusia selalu diperhatikan dan direkam melalui CCTV para malaikat. Perbuatan tersebut nantinya akan mendapatkan balasan yang setimpal dari Allah Swt. Oleh karenanya, rasa malu hendaknya ditumbuhkan pada diri sendiri ketika berbuat sesuatu yang buruk sehingga menjadikan diri sendiri lebih terhormat dan bermartabat.

${ }^{43}$ Ibnu Hajar Al-Asqalani, Fathul Baari: Penjelasan Kitab Shahih Al-Bukhari Jilid 1. Terj. Gazirah Abdi Ummah, (Jakarta: Pustaka Azzam, 2003), hlm. 87.

${ }^{44}$ QS. Al-Infithar [82]: 10-12.

${ }^{45}$ Syaikh Imam Al-Qurthubi, Tafsir Al-Qurthubi Jilid 20, ....hlm.160.

${ }^{46}$ Quraish Shihab, Tafsir Al-Misbah: Pesan, Kesan, dan Keserasian al-Qur'an, ....hlm. 129-300. 
Pesan penting yang harus tersampaikan kepada seluruh YouTuber adalah untuk memegang erat rasa malu dalam dirinya ketika berbuat yang tak pantas seperti asusila abu-abu. Hal ini terkait dengan kesadaran diri untuk merenungi kesalahan ataupun melakukan perbuatan maksiat. Pesan mulia ini hendaknya juga terus disuarakan oleh $d a^{\prime} i$ dan da'iyah di seluruh nusantara baik melalui media sosial maupun secara langsung untuk terus memupuk rasa malu pada diri sendiri ketika berbuat dosa. Namun yang terpenting adalah upaya pencegahan harus terus dilakukan dengan memberikan pendidikan karakter sejak dini baik di lingkungan keluarga maupun sekolah.

\section{Kesimpulan}

Sekali lagi bahwa fenomena asusila abu-abu yang beredar di YouTube kiranya mendapatkan perhatian lebih dari berbagai pihak. Sebab fenomena ini hanya dianggap sebagai sesuatu yang biasa, namun jika dibiarkan akan memberi dampak yang cukup serius terkait dengan adat ketimuran yang berlaku di Indonesia. Oleh karenanya, hifz al-irdi (menjaga kehormatan) menjadi penting untuk digagas dan senantiasa diterapkan dalam setiap aspek kehidupan. Di antara panduan Alquran guna menjaga kehormatan dalam bermedia sosial antara lain larangan membuat konten yang menimbulkan rangsangan seksual, memakai pakaian yang pantas, dan membudayakan rasa malu ketika membuat konten yang tidak layak. Hal ini bertujuan agar muru'ah atau harga diri tidak jatuh. Akhir kata, hifz al-irdi dapat menuntun manusia untuk menyikapi tingkah buruknya, karena sejatinya benih yang ditabur akan menghasilkan buah yang sama.

\section{Saran}

Sebagai pengguna maupun konten kreator YouTube sejatinya memiliki tanggung jawab penting untuk senantiasa memanfaatkan platform media sosial YouTube secara bijak. YouTube hendaknya dimanfaatkan untuk mensyiarkan kebaikan, pendidikan, dan berbagai dokumentasi penting yang lain. YouTube bukan 158 | El Madani: Jurnal Dakwah dan Komunikasi Islam, Volume 1 No. 02 (2020) 
Menghadirkan Hifz al-Irdi dalam Bermedia Sosial: Upaya Menyikapi Asusila Abu-abu di YouTube sekedar untuk menaikkan popularitas atau pun memperoleh royalti penghasilan belaka, melainkan YouTube sepatutnya dapat dijadikan washilah atau jalan untuk semakin banyak menebarkan amar makruf nahyi munkar kepada sesama melalui konten-konten yang bermanfaat.

\section{Daftar Pustaka}

\section{Buku}

Abdullah dan Irra Hegwisi. KPI A to Z: Panduan Implementasi KPI yang Workable. Jakarta: Grasindo, 2017.

Al-Asqalani, Ibnu Hajar. Fathul Baari: Penjelasan Kitab Shahih Al-Bukhari Jilid 1. Terj. Gazirah Abdi Ummah. Jakarta: Pustaka Azzam, 2003.

Al-Imam Abul Fida Ismail Ibnu Katsir ad-Dimasyqi. Tafsor al-Qur'anul 'Azhim. Beirut: Darul Fikr, 1983.

al-Jauziyah, Ibn Qayyim. Kiat Membersihkan Hati dari Kotoran Maksiat. Terj. Fauzi Bahreisy. Jakarta: Serambi Ilmu Semesta, 2008.

Al-Qurthubi, Syaikh Imam. Tafsir Al-Qurthubi Jilid 10. Terj. Asmuni. Jakarta: Pustaka Azzam, 2008.

Auda, Jasser. Membumikan Hukum Islam Melalui Maqasid Syariah, terj. Rosidin dan Ali Abd el-Mun'im. Bandung: Mizan Media Utama, 2015. . Maqasid al-Shariah as Philosophy of Islamic Law: a Sistem Approach. Malaysia: Vinlin Press, 2010.

Baghir, Muhammad. Panduan Lengkap Ibadah Menurut Al-Qur'an, Al-Sunnah, dan Pendapat Para Ulama. Jakarta: Naura Books, 2015.

Busyro. Maqasid al-Syariah: Pengetahuan Mendasar Memahami Masalah. Jakarta: Prenadamedia Group, 2019.

Djalil, A. Basiq. Ilmu Ushul Figh. Jakarta: Kencana Prenada Media Group, 2010.

Dzajuli. Kaidah-Kaidah Fikih: Kaidah-kaidah Hukum Islam dalam Menyelesaikan MasalahMasalah yang Praktis. Jakarta: Kencana, 2007. 
Katsir, Ibnu. Terjemah Singkat Tafsir Ibnu Katsir, terj. Salim Bahresy dan Said Bahresy. Surabaya: PT Bina Ilmu, 2002.

Mahali, A. Mujab. Asbabun Nuzul: Studi Pendalaman Al-Qur'an. Jakarta: PT Raja Grafindo Persada, 2002.

Mahmud, Wajih. Siapa Bilang Bersedekah Harus Tunggu Kaya?. Jakarta: Mizan, 2012.

Nasrullah. Resep Hidup Bahagia Menurut al-Qur'an. Jakarta: Pustaka Alvabet, 2019.

Sayyid Quthb. Tafsir Fi Zhilalil Qur'an. Terj. As'ad Yasin dkk. Jakarta: Gema Insani, 2013.

Shihab, Quraish. Jilbab, Pakaian Wanita Muslimah. Jakarta: Lentera Hati, 2012. . Tafsir Al-Misbah: Pesan, Kesan, dan Keserasian al-Qur'an. Jakarta: Lentera Hati, 2009.

Surbakti, E.b. Gangguan Kebahagiaan Anda dan Solusinya. Jakarta: Alex Media Komputindo, 2010.

Tim Redaksi KBBI. Kamus Besar Bahasa Indonesia. Jakarta: Badan Pengembangan dan Pembinaan Bahasa Kementerian Pendidikan dan Kebudayaan, 2017.

Yunus, Mahmud. Kamus Arab-Indonesia. Jakarta: Mahmud Yunus Wadzuryah, 1990.

Zed, Mestika. Metode Penelitian Kepustakaan. Jakarta: Yayasan Pustaka Obor Indonesia, 2014.

\section{Artikel Jurnal dan Skripsi}

Setiawan, Harinal. "Peranan Kepolisian dalam Menanggulangi Tindak Pidana Kejahatan Asusila yang Dilakukan Orang Dewasa terhadap Anak di Kota Pekanbaru". Jurnal Fakultas Hukum, Vol. 01, No. 02, 2014: 1-15.

Sidiq, Syahrul. “Maqasid Syari'ah dan Tantangan Modernitas: Sebuah Telaah Pemikiran Jasser Auda”. Jurnal Agama dan Hak Azazi Manusia, Vol 07, No. 01, 2017: 140-161.

Solikhah, Ulfa Dewi. Analisis Faktor yang Mempengaruhi Minat Pengguna Menjadikan YouTube Sebagai Sumber Penghasilan (Persepsi pada Mahasiswa Akuntansi Universitas Islam Indonesia). Skripsi, Universitas Islam Indonesia, 2018. 
Menghadirkan Hifz al-Irdi dalam Bermedia Sosial: Upaya Menyikapi Asusila Abu-abu di

\section{Artikel Internet (Berita Surat Kabar Online)}

Boyke Ledy Watra, Kominfo Utamakan Pembinaan untuk Konten Asusila “AbuAbu", $\quad$ https://www.antaranews.com/berita/1006538/kominfo-utamakanpembinaan-untuk-konten-asusila-abu-abu.

Sally Siahan, YouTuber Ajak Pacar Cantik 'Enak-enak' jadi Trending Youtube, Sempat Ditolak, Akhirnya Mau?, https://medan.tribunnews.com/2019/10/10/youtuber-ajak-pacar-cantik-enakenak-jadi-trending-youtube-sempat-ditolak-akhirnya-mau?page=3.

Kominfo, https://kominfo.go.id/content/detail/20636/kominfo-utamakan-pembinaanuntuk-konten-asusila-abu-abu/0/sorotan media.

Kominfo, Pornografi Masih Merajai Konten Negatif Indonesia, https://kominfo.go.id/content/detail/19631/pornografi-masih-merajaikonten-negatif-internet-indonesia/0/sorotan media.

Kementerian Pemberdayaan Perempuan dan Perlindungan Anak Republik Indonesia, Modul Creative Digital Education, 2017, https://www.kemenpppa.go.id/lib/uploads/list/990b7-creative-digitaleducation.pdf.

CNN Indonesia, https://www.cnnindonesia.com/teknologi/20150214143544-18532127/youtube-dalam-angka-angka.

Agus Tri Haryanto, https://inet.detik.com/cyberlife/d-3912429/130-juta-orangindonesia-tercatat-aktif-di-medsos. 
Saibatul Hamdi dan Khabib Musthofa

162 | El Madani: Jurnal Dakwah dan Komunikasi Islam, Volume 1 No. 02 (2020) 